験が終了したのでここに結果を整理して報告する.

瀻維集合体の吸音特性を支配する要因として考兄られ るものは，繊維自体関する長さ，太さ，表面形態拉よ び弾性率と集合体としての多孔度 (絨維量, かさ密度), 纎維の配列状態招よび厚さと試料の取付计条件, 周波数 などがあるが，今回は繊維の太さ，配列状態，多孔度と 厚さなどの要因を変化させて, それぞれの吸音特性を求 め, これらの要因がどのように吸音作用に影響している かを実験的に考察した。

\section{2. 実験方法と測定結果}

吸音率の測定法には定常波法と残響室法とがあるが, 理論的な考察に便利な定常波法によって垂直入射吸音率 $\alpha_{0}$ (以下単に吸音率と略す）を求めた。測定理論特よ び装置は既報の織物の吸音率を測定したときと同一で, 管の一端に試料を音波に対して垂直に置き，ある周波数 の定常波を作り, 試料面から数えて第一番目の極大音圧 と極小音圧の比 $N$ を抵抗減衰器で求め, 次式に代入して その周波数の吸音率とした。

$$
\alpha_{0}=4 /\left(N+N^{-1}+2\right)
$$

測定周波数は原則として $250 \mathrm{c} / \mathrm{s}$ から $1 / 3$ オクターブ 間隔に $2000 \mathrm{c} / \mathrm{s}$ までとし，必要なときにはそれらの間 の周波数についても吸音率を測定した。測定リングは第 1 図に示すような内面仕上 を施した厚さ $T=1.25$ ， $2.5,5 \mathrm{~cm}$ の真鍮リングで, その中に繊維を詰めて測定 管に装てんした，前面の金 網は直径 $0.8 \mathrm{~mm}$ で, 空間 $5 \mathrm{~mm}$ 平方である. この金 網の吸音率は検出できない ほど小さく，金網を必要と しない成型吸音材料につい て吸音率を求めたところ， 測定音域では金網の有無は まったく関係なかった。

試料は某工場の好意によ

り，同一条件で紡系した 1 ， $3,5 \mathrm{~d}$ のビスコース人綟 をトウのまま受け取り，所

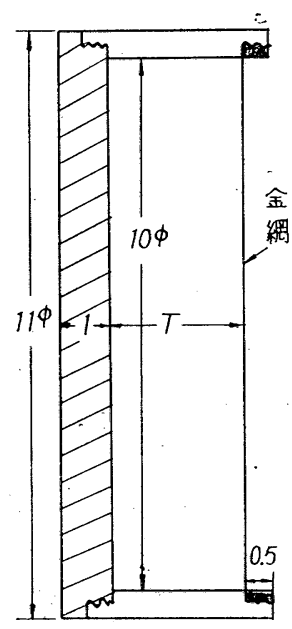

（第 1 図） 測定用リング (単位 $\mathrm{cm}$ ) $T=1.25,2.5,5 \mathrm{~cm}$
定の長さに切断したものを用いた（な抢比較のために ほかの纎維についても同様な測定を行なった）

\section{（実験 I）}

主として繊維の配列状態すなわち空げきの分布状態の 吸音特性への影響をみるために，1，5d を選び繊維長 $2.5 \mathrm{~cm}$ に切断し, 測定リング $T=2.5 \mathrm{~cm}$ につぎの 2 通 りに，それぞれ多孔度 $P$ を変えて詰めた。

（1）繊維配列; 平行（繊維の長さの方向が音波の進 行方向に平行)

（2） 繊維配列；垂直（繊維の長さの方向が音波の進 行方向に垂直)

これらの配列状態では多孔度が大きいと測定リングの

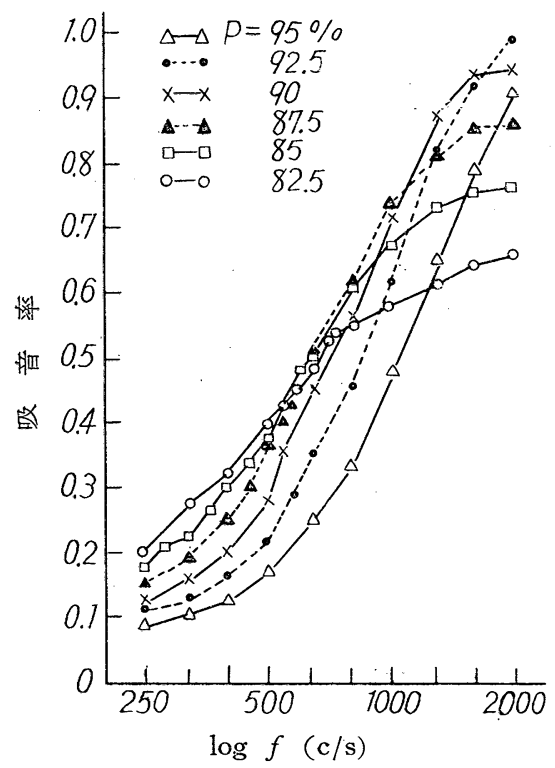

（第 2 図） $1 \mathrm{~d}$ 厚さ $2.5 \mathrm{~cm}$ の吸音特性 緎維方向：平行配列

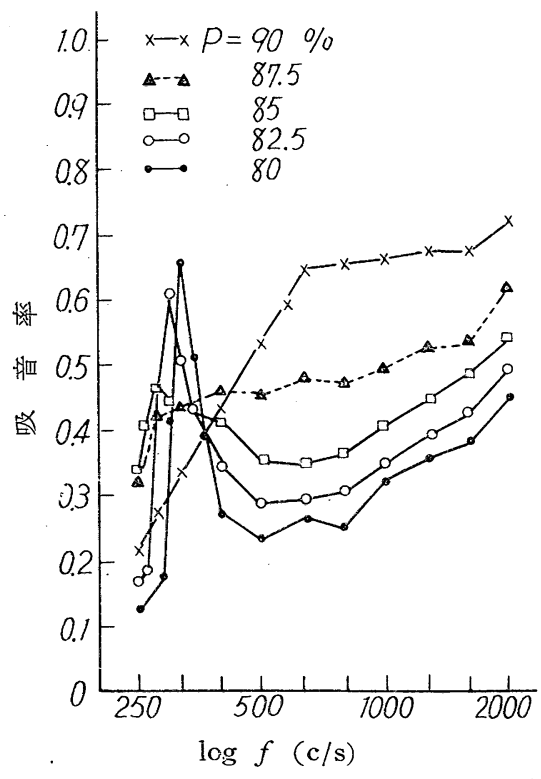

（第 3 図） $1 \mathrm{~d}$ 厚さ $2.5 \mathrm{~cm}$ の吸音特性 繊維方向：垂宜配列. 


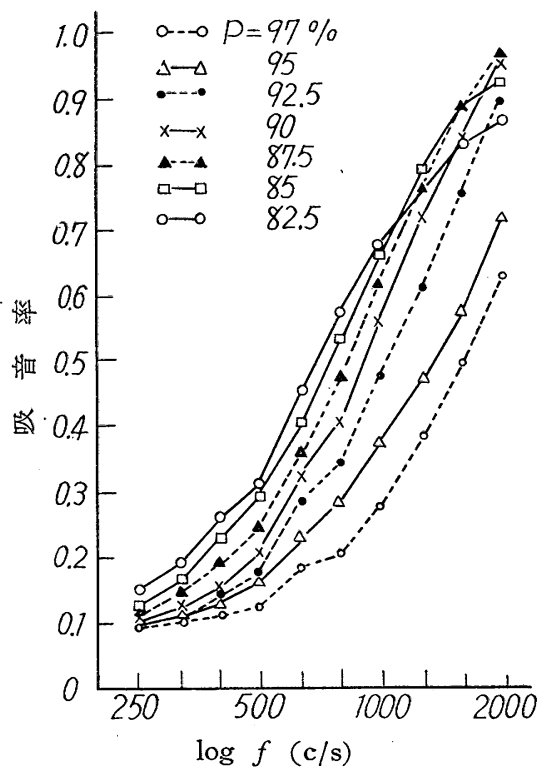

（第 4 図） $5 \mathrm{~d}$ 厚さ $2.5 \mathrm{~cm}$ の吸音特性 繶維方向：平行配列

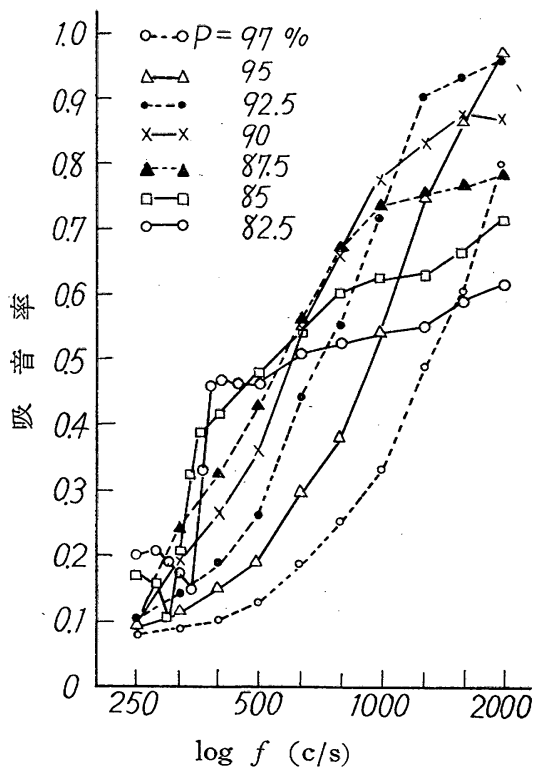

（第 5 図） $5 \mathrm{~d}$ 厚さ $2.5 \mathrm{~cm}$ の吸音特性 緎維方向：垂直配列

中で瀻維全体が下方に片寄って均一な分布が保持できな い. そこで $5 \mathrm{~d}$ では $P=97 \%$ まで，1d では $P=95 \%$ までとした．多孔度の小さい方は平行配列では $P=82.5$ $\%$, 垂直配列では $1 \mathrm{~d} P=80 \%, 5 \mathrm{~d} P=82.5 \%$ から 測定した。測定結果は第 $2 \sim 5$ 図にそれぞれの多孔度に ついて吸音の周波数特性曲線 (吸音特性) として示す. 第 3 図では図を簡素化するために $P=90 \%$ より大きい吸 音特性はその型が第 5 図の同一多孔度のそれと似ている
ので省略した。

(実験 II)

繊維集合体の総表面積と吸音率の関係をみるために, $3,5 \mathrm{~d}$ の繊維長 $2.5 \mathrm{~cm}$ を用い, 試料の厚さ $2.5 \mathrm{~cm}$ で繊維配列を平行, 垂直の場合につき, 総表面積が等し くなるよゔに採量して吸音特性を求めた。つぎにナイロ ンの $8 \times 2 \frac{1}{2}$ in, $5 \times 3$ in と $3 \times 2$ in を用いて, 緎維 配列をランダムにするためハンドカードで開毛して, $T=2.5 \mathrm{~cm}$ で同一総表面積にして吸音特性を求めた。 結果の一部を考察の項で図示する。（第17,18 図）

\section{（実験 面）}

主として試料の厚さと繊維の太さの影響を調べるため に, $1,3,5 \mathrm{~d}$ を $2.5 \mathrm{~cm}$ に切断し, ハンドカードで 開毛して繊維方向をランダム配列とし， $T=1.25,2.5$, $5 \mathrm{~cm}$ の測定リングを用い，それぞれ多孔度を変化させ て吸音特性を求めた。繊維方向がランダムであるから, 繊維相互のからみ合いで平行, 垂直の場合のようにリン グ内で片寄らず $P=99 \%$ まで均一に詰めることができ た. しかし多孔度が小さいと金網が流曲するので，この 心配のない $P=90 \%$ から測定した。結果は第6〜14図 に示す.

多孔度 $P(\%)$ に対する繊維の採取量 $W(\mathrm{~g})$ は次式 によった。

$$
W=V \rho(1-P / 100)
$$

ここにVは測定リングの容積， $\rho$ は繊維の密度である. また, 繊維集合体の総表面積 $S\left(\mathrm{~cm}^{2}\right)$ は次式によった.

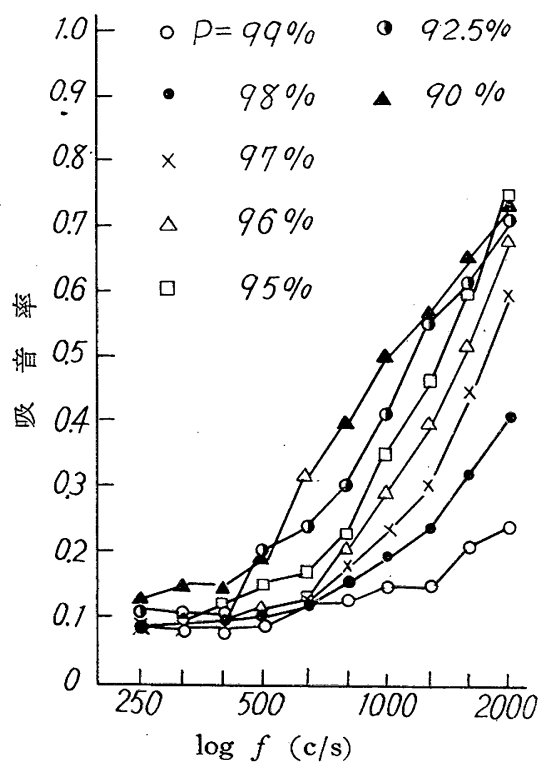

（第6 図） $1 \mathrm{~d}$ 厚さ $1.25 \mathrm{~cm}$ の吸音特性 (第 6〜14 図ランダム配列) 
$S=2 W(l+r) / \rho r l \fallingdotseq 2 W / \rho r$

ここに $l$ は繊維長, $r$ 注繊維半径で $r=(d / \pi L \rho)^{1 / 2}$ よ り計算した. $\left(d ;\right.$ デニール， $\left.L=9 \times 10^{5} \mathrm{~cm}\right)$

\section{3. 考察}

\section{1 吸音特性}

上述の実験結果に基づく吸音特性を総合的にみると, 曲線の型には繊維質材料の吸音特性として知られている ほかに，特異な曲線の型をしたものがある、いまこれら

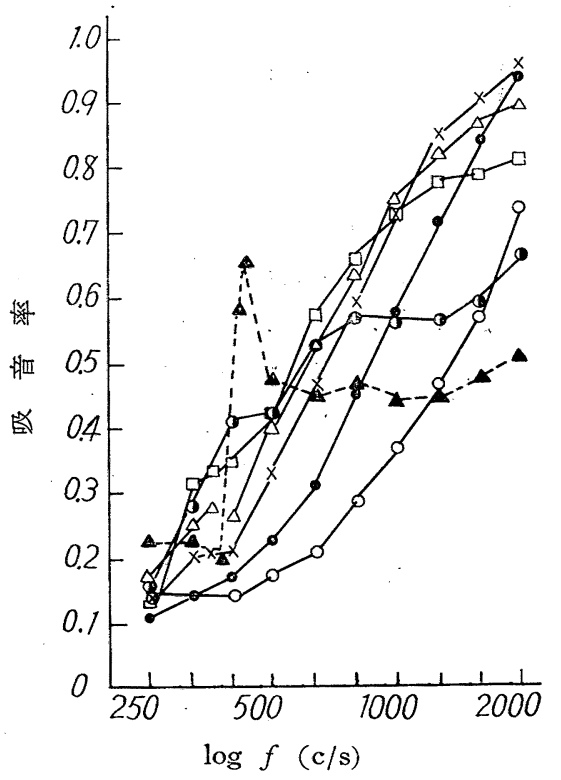

（第 7 図） $1 \mathrm{~d}$ 厚さ $2.5 \mathrm{~cm}$ の吸音特性

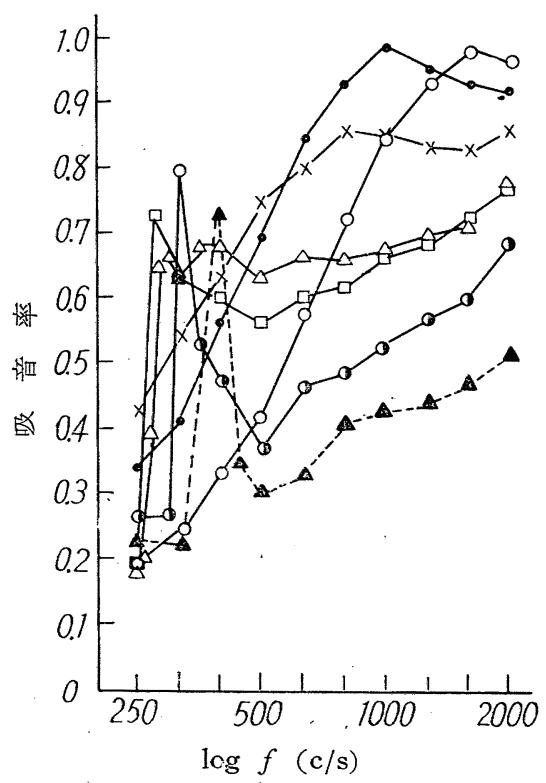

（第 8 図） $1 \mathrm{~d}$ 厚さ $5 \mathrm{~cm}$ の吸音特性
の中から典型的な例を抜きだすと第 15 図のように $3 つ$ の型がある.

I 型は繊維の吸音特性として知られている型で, 繊維 集合体中の空げきに音波が伝わり，その中の空気を振動 させると空気の粘性によって繊維表面との摩擦で音のエ ネルギの一部は熱エネルギに変換される吸音作用が主体 であるので，これを粘性抵抗型とする，この型に属する 吸音特性は高多孔度の試料にあらわれるから, 瀻維集合 体内部では一定音速であるとみなせば，試料内の定常波

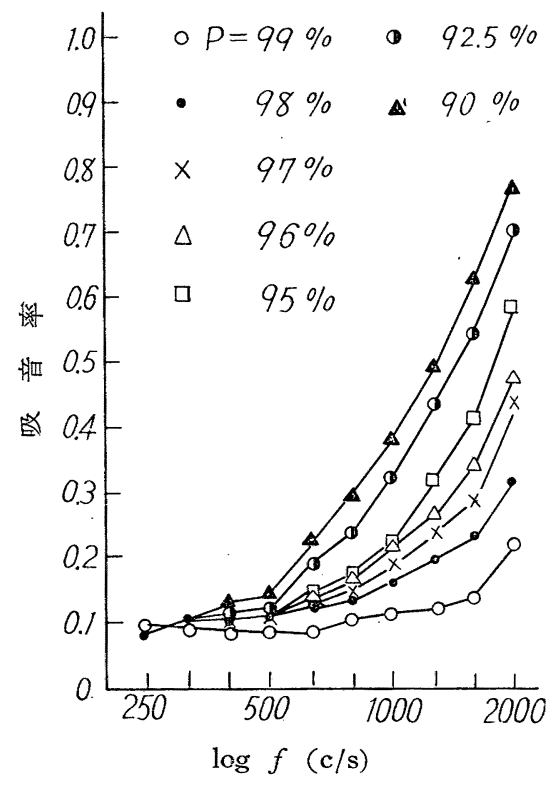

(第9 図) $3 \mathrm{~d}$ 厚さ $1.25 \mathrm{~cm}$ の吸音特性

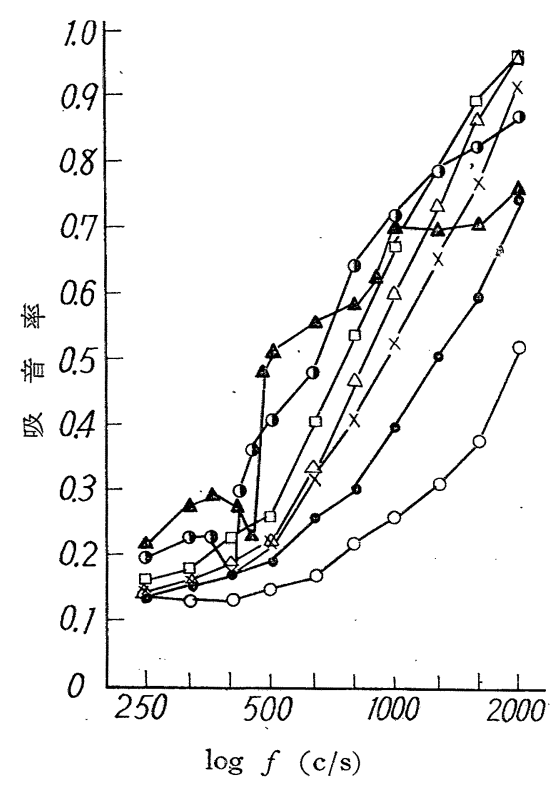

（第 10 図） $3 \mathrm{~d}$ 厚さ $2.5 \mathrm{~cm}$ の吸音特性 
の粒子速度Uは次式で示される。

$$
U=k\left(A_{i}^{2}+A_{r}^{2}-2 A_{i} A_{r} \cos 2 k x\right)^{1 / 2}
$$

ここに $k$ : 波長定数, $x$ : 試料後面からの距離, $A_{\imath}, A_{r}$ : 入射波, 反射波の速度ポテンシャルの振幅である。Uは $x=1 / 4$ 波長で極大值 $U=k\left(A_{i}+A_{r}\right)$ であるから, $k=$ $2 \pi f / c$ ( $f$ : 周波数, $c$ : 音波) で置換すれば明白なよう に，1/4波長以下の厚さでは，fの大きいほど，試料中に 粒子速度の大きい部分が入ってくるので，上述の吸音機 構に従って，周波数が高くなるほど，吸音率が大きくな

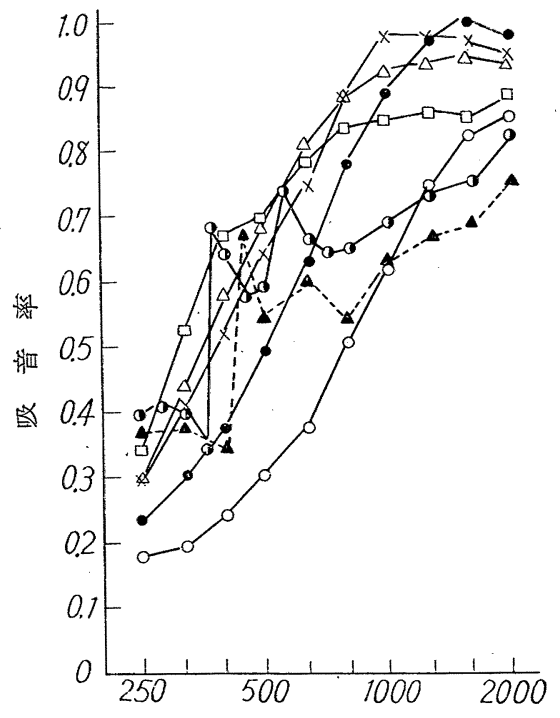

$\log f(\mathrm{c} / \mathrm{s})$

（第 11 図） $3 \mathrm{~d}$ 厚さ $5 \mathrm{~cm}$ の吸音特性

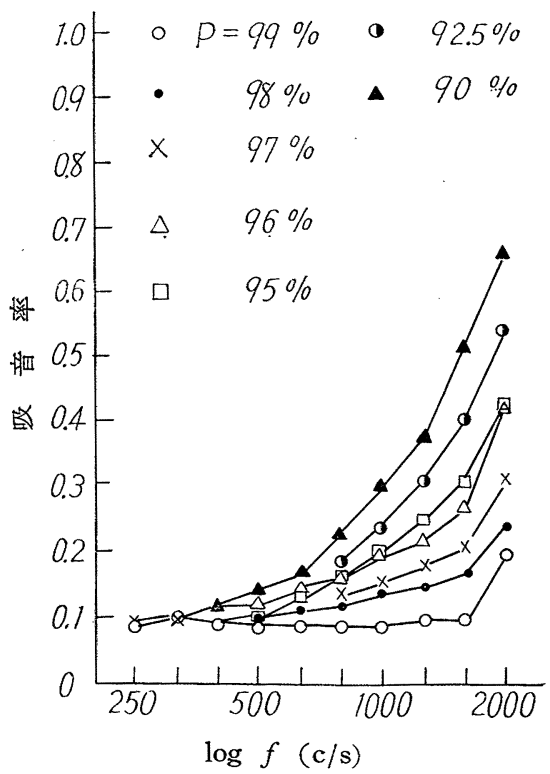

（第 12 図） $5 \mathrm{~d}$ 厚さ $1.25 \mathrm{~cm}$ の吸音特性
る.

II型はピークがあらわれているが、 ヘルムホルッの共 鳴器で代表される空気の共鳴とか, 膜, 板の共鳴吸収の 吸音特性と異なり，ピークの周波数より高い音域で吸音 率が周波数とともに増加している。この部分の吸音は I 型と同様な吸音機構が主体である。この型は低音域でピ 一クがあり, 高音域で吸音率が增加する吸音特性で, 緎 維集合体に独特な特性であるから，ピークを共鳴吸収と 考えて II 型を繊維質共鳴型とする。この型は繊維配列が

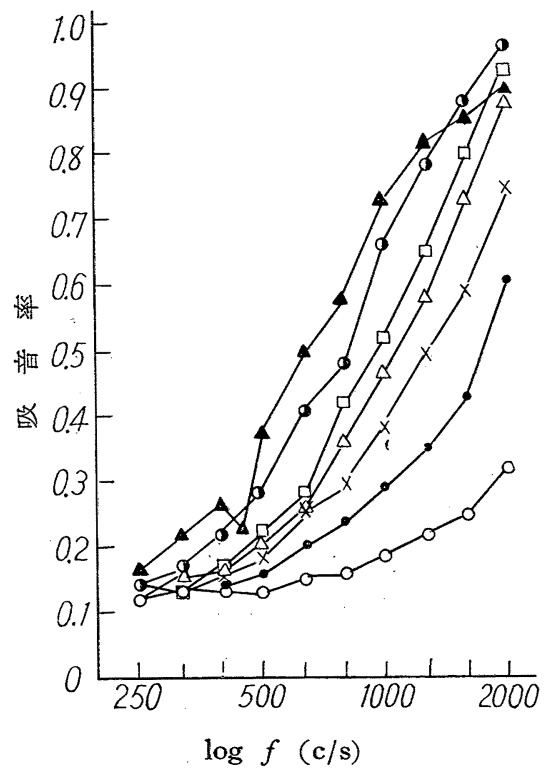

(第 13 図) $5 \mathrm{~d}$ 厚さ $2.5 \mathrm{~cm}$ の吸音特性

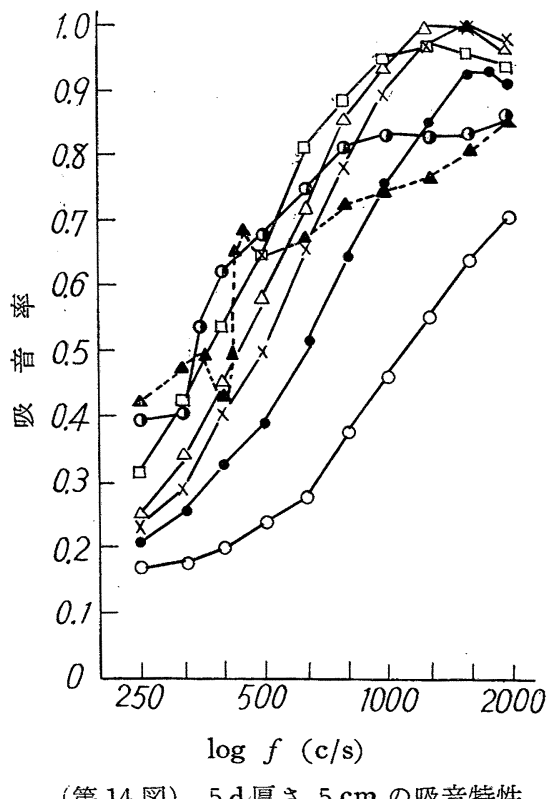

（第 14図） $5 \mathrm{~d}$ 厚さ $5 \mathrm{~cm}$ の吸音特性 


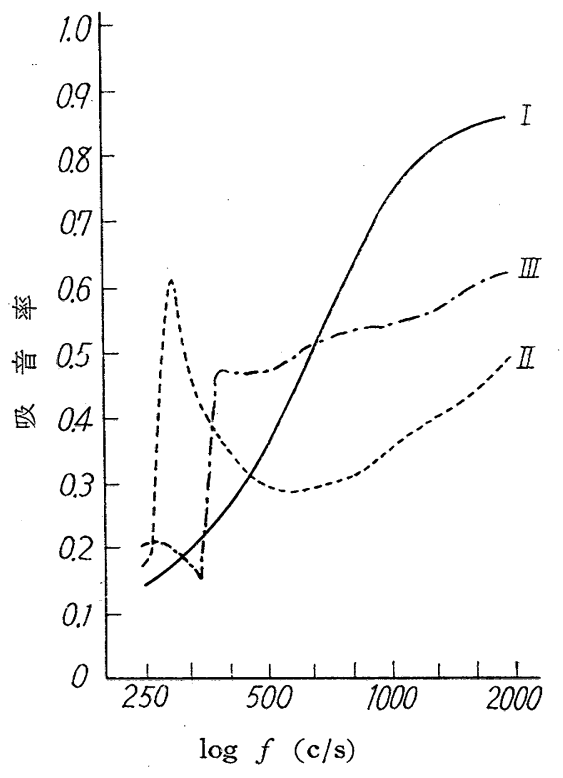

（第 15 図）繊維集合体の吸音特性の型

I : 粘性抵抗型 (1 d 多孔度 $87.5 \%$ 平行配列)

II : 緎維質共鳴型 (1 d 多孔度 $82.5 \%$ 垂直配列)

II : 中 間 型 $(5 \mathrm{~d}$ 多孔度 $82.5 \%$ 垂直配列)

垂直，ランダムで，低多孔度のとき顕著であり，平行配 列では測定範囲の多孔度では現われていない，この事実 から繊維集合体内部の空げきが前面から後面まで直通し ていて, 繊維相互の摩擦が小さい状態ではピークは起り がたく，瀻維間の摩擦が大きいか，あるいはからみ合い で緎維集合体が曲げ剛性を有する板状となり，測定リン グに周縁が固定されたと同样な状態になったとき，共振 周波数を持ち共鳴吸収が起きると考兄られる.

且型はI そ IIの中間であり，共鳴吸収があるが，共振 周波数より高音域で粘性抵抗型の吸音率が大きく,ピー クが現われない場合である，したがってこの型を中間型 とする。この型は第 10，14図の $P=90 \%$ にも明瞭に現 われているように共振周波数よりわずかに低い周波数で 吸音率が極度に低下し，それより低音域で吸音率の山が 現われ，あたか子共鳴吸収のような特性を示している。

そこでこの低音域の山が共鳴によるかつぎの実験で検討 した。

公称かさ密度 $32 \mathrm{~kg} / \mathrm{m}^{3}$, 厚さ $50 \mathrm{~mm}$ のグラスウー ル（ガラス繊維に樹脂加工を施し板状に成型したもの） を直径 $10 \mathrm{~cm}$ の真円にカッタで打抜き，測定リングに きちんとはめ込んだ状態 $(A)$ で吸音特性を求め,つぎ にこの試料の周囲をわずかに削り落し，測定リングに一 部だけ接した状態 $(B)$ で吸音特性を求めた。 $A$ 試料は $12.67 \mathrm{~g} ， B$ 試料は $12.07 \mathrm{~g}$ で $0.6 \mathrm{~g}$ 削り落しただけであ

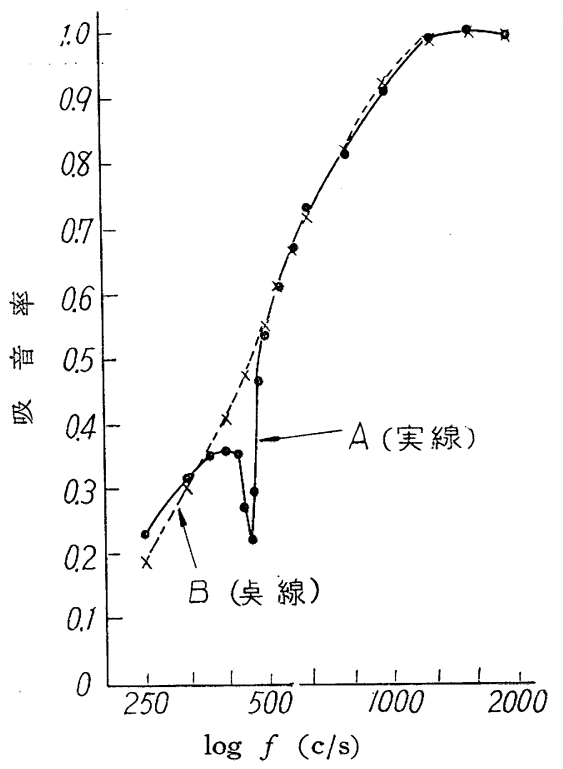

（第 16 図）グラスウールの吸音特性（厚さ $50 \mathrm{~mm}$ 公称汃密度 $32 \mathrm{~kg} / \mathrm{m}^{3}$ )

り,これによる粘性抵抗型の吸音率への影響はきん少で ある。この両吸音特性を第 16 図に示す，Aは中間型の 吸音特性で $400 \mathrm{c} / \mathrm{s}$ で極大, $450 \mathrm{c} / \mathrm{s}$ で極小值の吸音率 となっている，Bではこの谷が消觉，典型的な粘性抵抗 型である。るし $A$ の $400 \mathrm{c} / \mathrm{s}$ 付近の山が共鳴に起因する

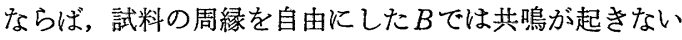
から吸音率が低くなるべきである。しかるにBでは同じ 位の吸音率である。したがってこの低音域の山は共鳴に よらず粘性抵抗型の吸音である。しかし試料の周縁が固 定された状態で生じる。この谷がなぜ現われるか現在で はあきらかでない。

\section{2 繊維の配列状態}

実験 I の結果の第 $2 \sim 5$ 図のほかに, 第 $7 \sim 13$ 図 る 韯維配列のみをランダムとし，その他の条件は実験 I と まったく同一の試料の吸音特性を示している。まずこの 配列条件で注目すべきことは平行配列であれば両デニー ルとも $P=82.5 \%$ まで瀻維量が增しても共鳴吸収が現わ れず粘性抵抗型の吸音特性を示している。 これに比べて 垂直配列では $1 \mathrm{~d}, P=85 \%$ で型， $5 \mathrm{~d} ， P=85 \%$ で 四型, ランダム配列では $1 \mathrm{~d}, P=96 \%$ で型, $P=90$ \%で II 型， $5 \mathrm{~d} ， P=90 \%$ で型の吸音特性を示してい る。前述のように，この配列によって共鳴吸収の有無が 決まることがピークが共鳴吸収であると推論される一つ の理由である.

さて同一多孔度（繊維量，かさ密度）でも配列条件に 
よって吸音特性を異にしているので定性的にこれらの原 因を考察する，音波の進行方向に平行に配列された試料 では，空げきが背面まで直通しているが，垂直，ランダ 厶配列では同じ空気量ですそれが細分されて分布してい る。したがって瀻維集合体中の音波の進行に対して平行 配列では瀻維表面との摩擦以外の抵抗が少ない。一方垂 直, ランダム配列では急收縮あるいは急拡大などの繰返 しがあり，瀻維表面との摩擦以外に音波の減衰が大き い. したがって含気量の多い高多孔度の繊維集合体では 同一繊維量でも平行配列の方が吸音率が小さい，しかし 低多孔度の繊維集合体では垂直ランダム配列の方が高い 周波数で吸音率が小さいのは，含気量が少なくなると平 行配列では内部まで音波が入りらる状態でも，垂直，ラ ンダム配列では音波の進行に対して抵抗が多過ぎて，内 部に入る割合が少なくなり吸音率が下ると考えられる。 この低多孔度に和敌る抵抗の增加は平行配列です当然生 じるが，その増加割合が垂直，ランダム配列の方が大き いために，このような吸音特性の違いとなって現われて いる。低多孔度の吸音特性が高音域で多孔度の低下とと あに吸音率が下るに反して，低音域では增加していると いう実験結果から，音波の進行に対する抵抗は周波数に 依存しており，同一条件では高い周波数に対する方が抵 抗が大きいと推察される。述の結果から所定の吸音率 をらるには，含まれている空気を細分するように配列し た方が繊維量が少なくてすむ．いま，垂直と平行の場合 の吸音率を比較すると $1,5 \mathrm{~d}$ とも平行配列の $P=82.5$ $\%$ \%゙垂直配列の $P=90 \%$ とほとんど一致する。

\section{3 総表面積}

粘性抵抗型の吸音機構が纎維表面と空気の摩擦に起因 しているならば，織維集合体の総表面積の大小が吸音率 に大き（作用することが当然考兄られる。逆腹同一総表 面積であれば吸音率も同じであると期待される。そこで 実験 II結果を第 17，18 図に示す。第 17 図はビスコー ス $5 \mathrm{~d}, P=90 \%$ の試料と, その総表面積に $3 \mathrm{~d}$ の総表 面積を一致させるように採量した $P=92.25 \%$ の試料を それぞれ配列状態を垂直，平行にして求めた吸音特性で ある。第 18 図は太さと長さが異なるナイロンを $3 \mathrm{~d}, P$ $=99 \%$ と $P=97 \%$ の総表面積に揃えるように採量して ランダム配列にした試料の吸音特性である。これらの試 料は総表面積を等しくしたために瀻維本数が異なり, 配 列が同じでも含有する空気量とその分布状態が違ってい る。したがって細空げきによる吸音への影響があり，吸 音特性がをったく一致するわけではないが，両図とすか

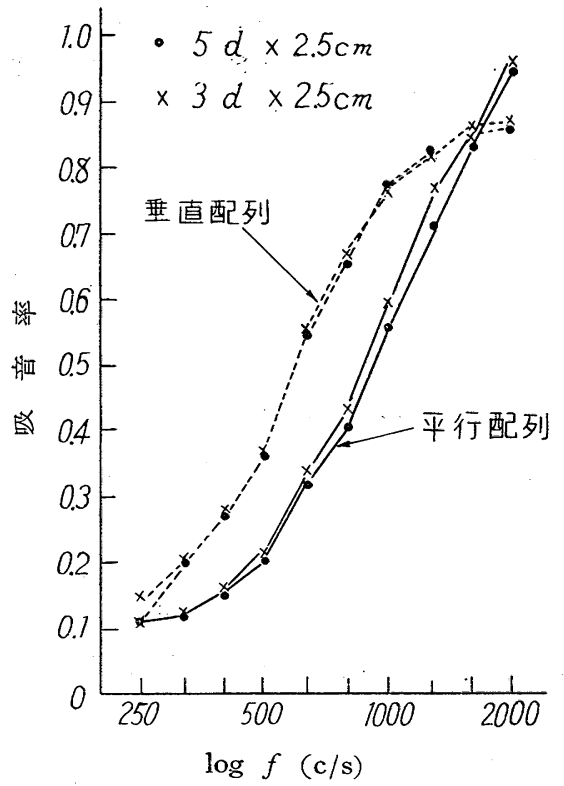

（第17 図）総表面積を一定にしを吸音特性 (ビスコース) 多孔度 $90 \%(5 \mathrm{~d})$

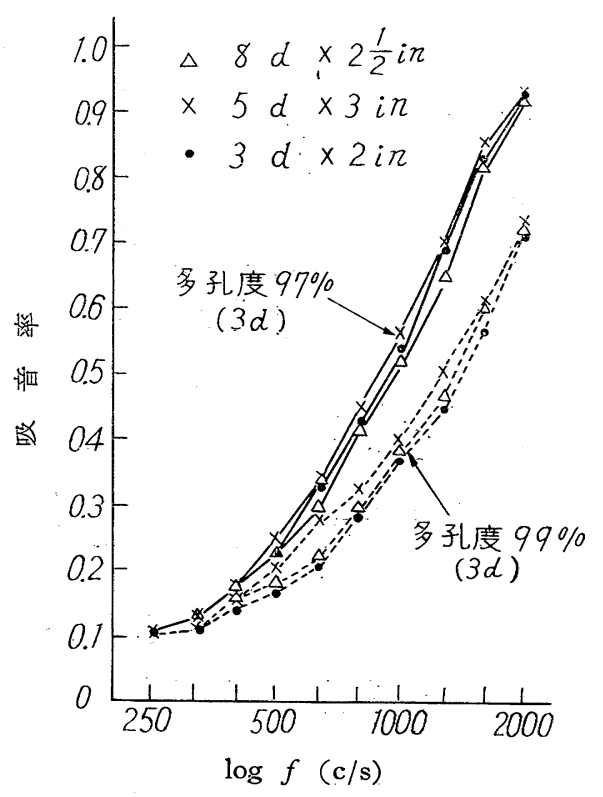

（第18 図）総表面積を一定にした吸音特性 (ナイロン）ランダム配列

なりよく一致している。この結果は粘性抵抗型の吸音機 構の推論が正しいことを証明するものであるが，これは 紐空げきの影響が小さいことが条件であるから，極端に 太い絨維と細い繊維の総表面積を一定に採量しても吸音 率は等しくならない。

実験胆の繊維の太さによる吸音率の相違は，この表面 積の効果と空げきの細分化によって説明される。すなわ 
ち高多孔度では細い方が吸音率が高いのは, 同一多孔度 でも総表面積が大きく，かつ本数が多いので空げきが細 分化されているためである。低多孔度では細い繊維ほど 音波の進行に対して抵抗が多過ぎるために，吸音率が低 下してくる.

\section{4 厚さ}

纎維集合体の総表面が等しければ，厚さと配列状態が 同一な試料については吸音特性が一致することが判明し たが，つぎに総表面積が一定で, 試料の厚さが異なる場 合を考えてみる，1d では総表面積 $S=16.3 \times 10^{3} \mathrm{~cm}^{2}$, $5 \mathrm{~d} て ゙ は S=7.28 \times 10^{3} \mathrm{~cm}^{2}$ に採量して, 瀻維の配列状態 をランダムにして厚さ $T_{1}=1.25, T_{2}=2.50, T_{3}=5.00$ cm の試料として求めた吸音特性を並記すれば，第 19 図 の通りである。すなわち繊維表面積が同じでも試料の厚

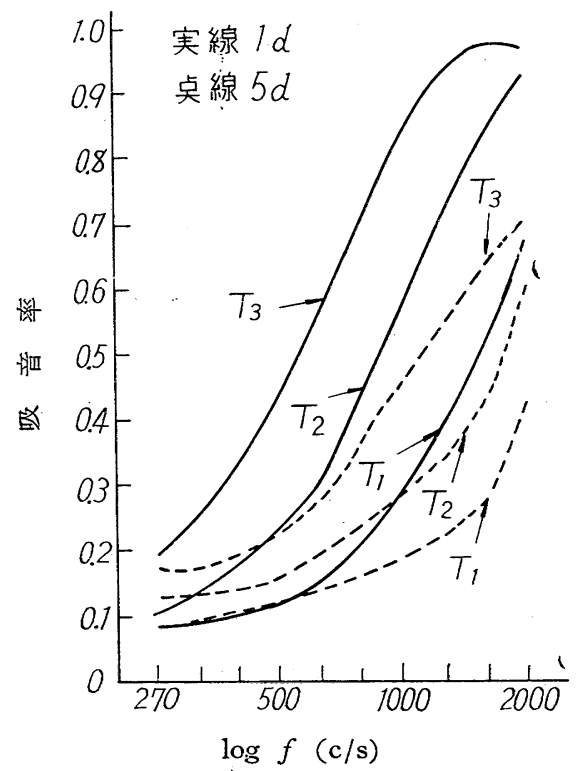

（第19図）一定総表面積で厚さを变化させた吸 音特性（厚さ: $T_{1}=1.25, T_{2}=2.5$, $T_{3}={ }^{3} 5 \mathrm{~cm}$ )

さが変れば吸音率は大きく変化する，試料が厚くなると 薄い試料の吸音特性を低音域の方へ移動させたような吸 音特性となる。したがって瀻維を少量用いて低音の吸音 率を大さくするためには厚さを増すことが有利である. これは（1）式にあきらかのごとく，厚くなれば同一周 波数で; 試料中に粒子速度の大きい部分が入ってくるか らであり，粘性抵抗型の吸音機構をとる試料については 普遍的にいえる。しかし試料の㳯さが1 $/ 4$ 波長以上になれ ば，その周波数に対する吸音率は当然低下する。，いま， ある周波数で極大吸音率を示す厚ざ有効厚さとすれば

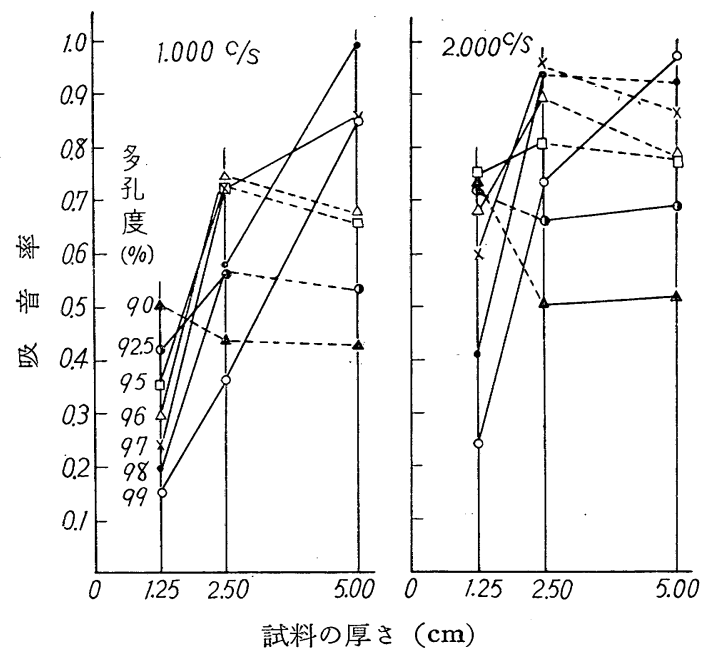

（第 20 図）試料の厚さと吸音率との関係 (1d ビスコース $2.5 \mathrm{~cm}$ cut 緘維方 向：ランダム配列)

有効厚さは試料の瀻維量によって左右される．各多孔度 について厚さと吸音率の関係を 1000 と $2000 \mathrm{c} / \mathrm{s}$ につ いてみると第 20 図の通りである。高多孔度では厚さと ともに吸音率が増加する，多孔度が小さくなると有効厚 さが現われ，上り低多孔度では有効厚さは $1.25 \mathrm{~cm}$ 以下 になる，図からあきらかのように有効厚さは㵶維量が多 く，周波数が大きい注ど小さく，かつ空気中の音速から 計算される1/4波長より短い。これは繊維集合体中の伝播 定数や音速が異なるためである.

\section{5 多孔度}

多孔度が小さくなると繊維量が多くなるので一定周波 数では吸音率は増加する。しかし高い周波数ではある多 孔度で極大吸音率 $\alpha_{m}$ を示し，これより低多孔度では除 々に減少する。 いまこの傾向を明確にするために一例と して, $1 \mathrm{~d}, T=2.5 \mathrm{~cm}$, 周波数 $1000,2000 \mathrm{c} / \mathrm{s}$ につい

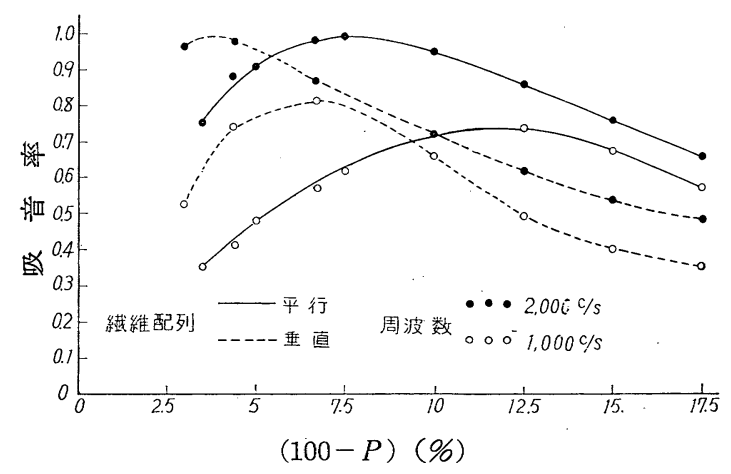

(第 21 図) 多孔度 $(P \%)$ と吸音率の関係 (試料厚さ $2.5 \mathrm{~cm}$, ビスコース $1 \mathrm{~d}$ ) 
て多孔度と吸音率の関係を図示すると第 21 図の通りで ある.この例では繊維配列が平行の場合, $2000 \mathrm{c} / \mathrm{s}$ で $P=92.5 \%$ のさ $\alpha_{m}=0.99,1000 \mathrm{c} / \mathrm{s}$ で $P=87 \%$ の とき $\alpha_{m}=0.74$ を示している. この傾向は配列のいかん を問わず現われ，低い周波数ほど，小さい多孔度で極大 吸音率を示す。この極大吸音率を示す多孔度を，その周 波数 $f$ の有効多孔度 $P_{e}$ とする。 いろいろな条件の試料 の吸音特性から第 21 図 と同樣にして，各周波数に対す る有効多孔度を求め両者の関係をみると第 22 困のごと

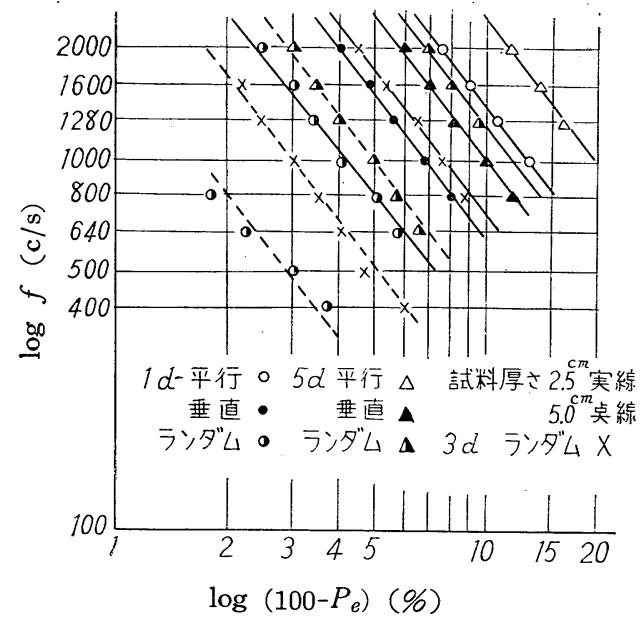

(第 22 図) 周波数 $(f \mathrm{c} / \mathrm{s})$ 之有効多孔度 $\left(P_{e} \%\right)$ との関係

くなる. 試料の厚さ $5 \mathrm{~cm} て ゙, 1$ と $3 \mathrm{~d}$ の場合は高い周 波数で有効多孔度が $P=99$ 98\%の間にあるが，測定を $P=99$ ，98\%についてだけ行なったために， $\alpha_{m}$ を決め ることができないので省略した，図から周波数と有効多 孔度との関係は

$$
\dot{f}=K\left(100-P_{e}\right)^{-a}
$$

で示される，この関係はナイロン，ビニロン，アセテー トなどの測定結果についてもみられる。したがっていは 繊維の種類, 配列状態, 纎維の太さにかかわらす゚一定で $a=1.3$ である. ただし $T=1.25 \mathrm{~cm}$ では $P_{e} か ゙ ，$ 測定範 囲の音域で現われなかったので $T=2.5,5.0 \mathrm{~cm}$ の結果 によった. $K$ は繊維の種類, 太さ, 配列状態々試料の厚 さなどによって定まる定数である，第 22 図から推察す れば繊維が細いほどKは小さい，配列状態が平行である とKは大きいが，垂直とランダムでは一義的に決まらな い. 試料の厚さについては薄い方が $K$ は大きいが， 1 , $3,5 \mathrm{~d}$ のランダム配列 $T=2.5 \mathrm{~cm}$ の $K=K_{2.5}, T=$ $5.0 \mathrm{~cm}$ の $K=K_{5.0}$ とすれば $K_{2.5} / K_{5.0}=3.2$ で一定であ る：したがって繊維の太さと配列状態を定めた試料につ
き，ある周波数で極大吸音率を示す有効多孔度を求めれ ば,（2）式より直ちに $K$ が定まり，任意の周波数に対 して極大吸音率を与える多孔度が求をる。

つぎに有効多孔度の極大吸音率とそのときの周波数と の関係をみると第 23 図の通りである。ここには一例と

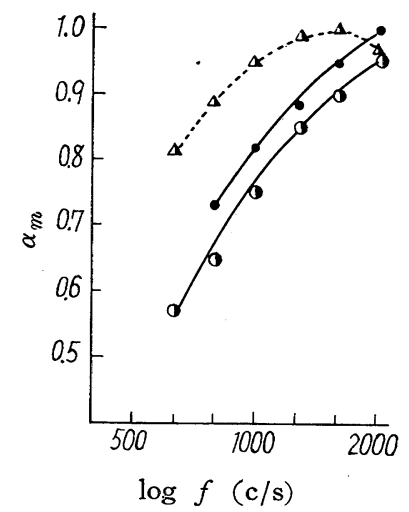

（第 23 図）極大吸音率 $\left(\alpha_{m}\right)$ 乙周波数 $(f \mathrm{c} / \mathrm{s})$ との関係

○: 厚さ $2.5 \mathrm{~cm}$ ランダム配列 $1 \mathrm{~d}$

: 厚さ $2.5 \mathrm{~cm}$ 垂直配 列 $1 \mathrm{~d}$

ム：厚さ $5.0 \mathrm{~cm}$ ランダム配列 $5 \mathrm{~d}$

して $1 \mathrm{~d}, T=2.5 \mathrm{~cm}$ の垂直とランダム配列就よび $5 \mathrm{~d}$ ， $T=5.0 \mathrm{~cm}$ のランダム配列について示してあるが，他 の条件のときも同一傾向である，試料の厚さ $T=5.0 \mathrm{~cm}$ についてみると周波数の増加につれて極大吸音率も大き くなり，ある周波数で最大吸音率になりふたたび減少す る.この最大吸音率を示す周波数の有効多孔度を最適有 効多孔度 $P_{m e}$ とする. いま測定周波数範囲に最大吸音率 が現われる厚さ $5 \mathrm{~cm}$ についてみると，5dでは第 23 図 から最大吸音率を示す周波数 $f=1600 \mathrm{c} / \mathrm{s}$, この周波数 の有効多孔度を第 22 図から求めれば，最適有効多孔度 $P_{m e}=96.6 \%$ である. $3 \mathrm{~d}$ では図は省略するが，同様に して求めれば, $P_{m e}=97.75 \%(1400 \sim 1600 \mathrm{c} / \mathrm{s}) 1 \mathrm{~d} て ゙$ は第 22 困を外々うして推定すると $P_{m e}=98.5 \%$ (1 200 $\mathrm{c} / \mathrm{s})$ である. 試料の厚さ $T=2.5 \mathrm{~cm}$ の場合は, $T=5.0$ $\mathrm{cm}$ の特性曲線を高音域に移動させた型となって抽り, 測定範囲の周波数では最適有効多孔度が現われず, 2000 $\mathrm{c} / \mathrm{s}$ に対する有効多孔度がもっとも大きい吸音率を示 す.

\section{4.むす び}

瀻維集合体の吸音作用に影響を及活すと考えられる要 因について，できるだけ独立にその要因を変化させた試 料を作り，各周波数の吸音率を測定して吸音特性を求め 
た. かくして得られた多数の実験結果に基づき各要因の 影響を検討した。これらの結果は摘要に記載したので省 略するが，緎維集合体の吸音作用を大きくするためには 一ロにいって構成繊維の総表面積を大さくし，含有する 空気を細分化するように配列することである。

現在市眅されている繊維質吸音材は厚さとかさ密度を 表示してあるが，今度の実験結果からして，瀻維の太さ （分布）も表示することが望亲しい，な和厚さとかさ密 度 (多孔度) には周波数に対して有效值があるので，実 際に使用するときはこれに留意する必要がある.

今回は実験結果から考察したが，これらの問題は瀻維 集合体の音響インピーダンス，伝播定数々音速の方面か ら理論的に考察する必要もあるので, これらの問題につ いては別の機会にゆずりたい.

本実験について直接ご指導いただいた小林理学研究所 建築音響室の子安勝先生に深く感謝する。な和いろいる とご教示下さった同室の久保啓一氏掹礼申し上げる.
また実験以の測定は高木利之君（現在ブリジストンタイ ヤ）をわずらわした，ここに記して感謝する。

\section{文献}

1) C. Zwikker, C. W: Kosten : Sound Absorbing Materials; Elsevier Publishing Co. (1949) E. G. Richardson : Technical Aspects of Sound; Elsevier Publishing Co. (1953)

Y. Kawashima: Acustica, 10, 208 (1960)

2) 日本音響材料協会編; 建築音響工学; 技報堂 (1963)

3 ) 子安勝: 小林理学研究所報告, 11, 65 (1961)

4 ) 子安勝：小林理学研究所報告, 12, 7 (1962)

5 ) 浅生, 木下, 子安: 日本音響学会研究発表会 (1960-10)

浅生, 木下: 本学会研究発表会 (1961-5)

6) 浅生, 木下: 本誌, 14, 285 (1961)

7 ) 浅生, 木下: 緎維学会研究発表会 (1961-10) 